\title{
STUDI KUALITATIF DAN KUANTITATIF MINYAK GORENG YANG DIGUNAKAN OLEH PENJUAL GORENGAN DI KOTA SUMBAWA
}

\author{
Destri Ariani, Sahri Yanti, Dinar Suksmayu Saputri \\ Fakultas Teknologi Pertanian, Program Studi Teknologi Hasil Pertanian \\ sahri.farwana@gmail.com
}

\begin{abstract}
Minyak goreng merupakan salah satu bahan pokok yang digunakan oleh penjual gorengan sebagai media pengolahan gorengan. Akan tetapi, penggunaan minyak goreng secara berulang dapat mempengaruhi kualitas minyak goreng dan memberikan dampak negatif bagi tubuh apabila dikonsumsi dalam jangka panjang. Penelitian ini bertujuan untuk mengetahui perubahan mutu minyak goreng dan kelayakan konsumsi gorengan di Kota Sumbawa berdasarkan analisis fisiko-kimia meliputi uji warna, uji organoleptik bau, uji kadar air, bilangan asam, bilangan peroksida, dan cemaran logam menggunakan alat Spektrofotometer Serapan Atom. Dari penelitian ini diperoleh hasil uji kualitas sampel minyak goreng untuk uji kadar air 0,1365-0,5156\%, bilangan asam 0,482-3,444 $\mathrm{mg} \mathrm{KOH} / \mathrm{gr}$, bilangan peroksida 6-30,8 mek $\mathrm{O}_{2} / \mathrm{kg}$, cemaran logam Kadmium (Cd) 0,0001-0,0003 mg/kg dan cemaran logam Timbal $(\mathrm{Pb})$ 0,0001-0,0011 $\mathrm{mg} / \mathrm{kg}$. Hasil penelitian terhadap 9 sampel yang diuji, menunjukkan bahwa semua sampel uji tidak memenuhi syarat mutu minyak goreng berdasarkan SNI 01-3741-2013, namun pada uji cemaran logam Kadmium (Cd) dan Timbal (Pb), semuanya berada dibawah maksimal cemaran logam.
\end{abstract}

Kata kunci: Minyak goreng, analisis fisiko-kimia, Sampel tidak memenuhi Standar SNI

\section{Pendahuluan}

Minyak goreng adalah bahan pangan dengan komposisi utama dari trigliserida dengan atau tanpa perubahan kimiawi. Pada umumnya berbentuk cair pada suhu ruang dan digunakan untuk menggoreng makanan (Sugiati dalam Chairunisa, 2013). Sedangkan menurut Haryono et al (2010) minyak goreng merupakan minyak yang telah mengalami proses pemurnian yang meliputi degumming, netralisasi, pemucatan, deodorisasi. Minyak goreng kebanyakan diperoleh dari tumbuhan seperti kelapa, kelapa sawit, kacang-kacangan, jagung dan kanola.

Minyak goreng mengandung zat yang penting untuk menjaga kesehatan tubuh manusia. Minyak goreng juga berperan memberi nilai kalori paling besar diantara zat gizi lainnya. Sebagian kecil minyak goreng akan diserap oleh bahan pangan yang digoreng sehingga m emberikan rasa gurih, kenampakan bahan bakanan menjadi lebih menarik, serta tekstur permukaan yang kering (Winarno dalam Aminah, 2010).

Minyak goreng adalah salah satu kebutuhan pokok masyarakat Sumbawa, selain untuk keperluan rumah tangga, juga banyak gunakan oleh penjual gorengan di Kota Sumbawa. Minyak goreng yang digunakan bervariasi, seperti minyak goreng kemasan botol, derrigent maupun reffil (isi ulang). Namun tidak dipungkiri, masyarakat yang berpenghasilan menengah kebawah masih banyak yang menggunakan minyak goreng curah yang harganya lebih murah.

Akan tetapi munculnya masalah tentang penggunaan minyak goreng jelantah atau penggunaan minyak goreng secara berulang cukup meresahkan masyarakatyang kadangkala tidak dapat dikenali dari tampilan produk gorengan. Apabila minyak goreng dipanaskan berulang kali pada suhu tinggi $\left(150-200^{\circ} \mathrm{C}\right)$ akan menyebabkan kerusakan minyak atau lemak sehingga mengakibatkan keracunan dalam tubuh dan munculnya berbagai macam penyakit, misalnya pengendapan lemak dalam pembuluh darah, kanker dan menurunkan nilai cerna lemak (Khomsan dalam Fauziah, 2014). Kecenderungan ini disebabkan oleh faktor ekonomi, rasa sayang dan merasa rugi jika minyak goreng tersebut tidak digunakan karena harus dibuang dan diganti dengan yang baru. Sehingga, secara langsung kualitas minyak goreng yang digunakan akan mempengaruhi cita rasa dan layak atau tidaknya gorengan itu dikonsumsi. Berdasarkan uraian diatas, untuk itu penelitian ini akan fokus pada "Studi Kualitas Minyak Goreng sebagai Analisis Kelayakan Konsumsi Gorengan di Kota Sumbawa". Analisis ini berdasarkan sifat 
fisiko-kimia yang meliputi uji organoleptik, analisis kadar air, uji bilangan asam, bilangan peroksida serta kandungan logam pada sampel minyak goreng yang telah digunakan oleh pedagang kaki lima dan penjual makanan cepat saji.

\section{Tinjauan Pustaka}

Minyak goreng adalah minyak yang berasal dari lemak tumbuhan atau lemak hewan yang dimurnikan dan berbentuk cair pada suhu ruang dan biasanya digunakan untuk menggoreng makanan (Sitepoe dalam Noriko dkk, 2012). Sedangkan menurut SNI (2013), minyak goreng adalah bahan pangan dengan komposisi utama trigliserida yang berasal dari bahan nabati, dengan atau tanpa perubahan kimiawi, termasuk hidrogenesis, pendinginan dan telah melalui proses refinasi atau pemurnian yang digunakan untuk menggoreng.

Minyak goreng berfungsi sebagai penghantar panas, memberi tekstur renyah dan menambah rasa gurih serta menambah nilai kalori pada bahan pangan yang digoreng. Setelah dilakukan penggorengan maka akan menghasilkan sisa minyak goreng yang lebih dikenal dengan sebutan minyak jelantah. Minyak jelantah adalah minyak yang dihasilkan dari sisa penggorengan dan dapat menyebabkan minyak berasap atau berbusa pada saat penggorengan, berwarna coklat, serta flavour yang tidak disukai dari makanan yang digoreng (Hambali, 2007).

Dalam minyak nabati terkandung asam-asam lemak yang tidak dapat diproduksi oleh tubuh manusia yang dapat mencegah penyempitan pembuluh darah akibat penumpukan kolesterol. Lebih lengkapnya disajikan jenis-jenis asam lemak yang terdapat pada minyak nabati yang dapat digunakan untuk menggoreng sesuai dengan Tabel

Tabel Komposisi Asam Lemak Dalam Tiga Minyak Nabati

\begin{tabular}{lcccc}
\hline Asam Lemak & $\begin{array}{c}\text { JumLah } \\
\text { Ataom C }\end{array}$ & $\begin{array}{c}\text { Minyak } \\
\text { Sawit (\%) }\end{array}$ & $\begin{array}{c}\text { Minyak } \\
\text { Inti (\%) }\end{array}$ & $\begin{array}{c}\text { Minyak } \\
\text { Kelapa (\%) }\end{array}$ \\
\hline \multicolumn{2}{l}{ Asam Lemak Jenuh: } & & & \\
Oktanoat & 8 & - & $2-4$ & 8 \\
Dekanoat & 10 & - & $3-7$ & 7 \\
Laurat & 12 & 1 & $41-55$ & 48 \\
Mirista & 14 & $1-2$ & $14-19$ & 17 \\
Palmitat & 16 & $32-47$ & $6-10$ & 9 \\
Stearat & 18 & $4-10$ & $1-4$ & 2 \\
Asam Lemak Tak Jenuh : & & & \\
Oleat & 18 & $38-50$ & $10-20$ & 6 \\
Linoleat & 18 & $5-14$ & $1-5$ & 3 \\
Linolenat & 18 & 1 & $1-5$ & - \\
\hline
\end{tabular}

Sumber: Majalah Sasaran No.4 dalam Noriko dkk, 2012<smiles>[R]C(=O)OCC(COC([R])=O)OC([R2])=O</smiles>

Gambar Struktur Kimia Minyak dan Lemak Asam lemak jenuh adalah asam lemak yang tidak memiliki ikatan rangkap pada atom karbonnya. Asam lemak yang bersifat jenuh juga merupakan asam lemak dengan rantai tunggal, biasanya terdapat dalam lemak atau minyak yang berasal dari hewan. Asam lemak jenuh seperti asam laurat, asam miristat, dan asam stearat ini yang dapat menyebabkan penyumbatan pembuluh darah yang fatalnya menyebabkan serangan stroke. Berikut adalah struktur kimia asam lemak jenuh sesuai dengan Gambar 2.2<smiles>CCCCCCC(C)C(=O)O</smiles> 
Gambar 2.2 Struktur Kimia Asam Lemak Jenuh

Asam lemak tak jenuh yaitu, bila rantai hidrokarbonnya tidak dijenuhi oleh hidrogen dan karena itu mempunyai satu ikatan rangkap atau lebih. Asam lemak tak jenuh mudah rusak apabila terkena panas tetapi sangat bermanfaat bagi kesehatan. Contoh asam lemak tak jenuh adalah linoleat, linolenat, dan arakidonat yang berfungsi mencegah penyumbatan pembuluh darah. Berikut adalah struktur kimia asam lemak tak jenuh sesuai dengan Gambar 2.3<smiles>CC=C=C=C=C=CC(=O)O</smiles>

Gambar 2.3 Struktur Kimia Asam Lemak Tak Jenuh

Berdasarkan rumusan yang ada dari Badan Standarisasi Nasional (BSN) tentang mutu minyak goreng berdasarkan Standar Nasional Indonesia (SNI) yaitu SNI 01-3741-2013 menetapkan bahwa standar mutu minyak goreng seperti pada Tabel 2.2 berikut ini :

Tabel 2.2 Standar Mutu Minyak Goreng Berdasarkan SNI 01-3741-2013

\begin{tabular}{lll}
\hline \multicolumn{1}{c}{ Kriteria Uji } & \multicolumn{2}{c}{ Persyaratan } \\
\cline { 2 - 3 } & Satuan & Mutu \\
\hline Keadaan & & Normal \\
1. Bau & & Normal \\
2. Warna & $\%(\mathrm{~b} / \mathrm{b})$ & Maks 0,15 \\
Kadar Air dan Bahan & & \\
Menguap & $\mathrm{mg} \mathrm{KOH} / \mathrm{gr}$ & Maks 0,6 \\
Bilangan Asam & $\mathrm{mek} \mathrm{O} / \mathrm{kg}$ & Maks 10 \\
Bilangan Peroksida & & \\
$\begin{array}{l}\text { Cemaran Logam } \\
\text { 1. Timbal }(\mathrm{Pb})\end{array}$ & $\mathrm{mg} / \mathrm{kg}$ & Maks 0,1 \\
2. Kadmium $(\mathrm{Cd})$ & $\mathrm{mg} / \mathrm{kg}$ & Maks 0,2 \\
\hline
\end{tabular}

Sumber : Standar Nasional Indonesia (2013).

\section{Metodologi Penelitian}

Sampel dalam penelitian ini adalah minyak goreng (bimoli) sebagai standar dan sampel uji adalah minyak goreng yang telah digunakan (minyak jelantah) oleh pedagang kaki lima dan penjual cepat saji di sekitaran Kota Sumbawa, seperti Labuhan Sumbawa, Terminal Sumer Payung, Lempeh, Brang Biji, Kampung Bugis, Seketeng, Quick Chicken (samping Pragas), Rocket Chicken, dan Amazy Chicken (Sumbawa Great Mall). Sampel kemudian diuji warna, bau, bilangan asam, peroksida, kada air dan cemaran logam.

\section{Hasil dan Pembahasan}

Hasil Uji Warna

Tabel 4.4 Hasil Uji Warna Minyak Goreng

\begin{tabular}{lllll}
\hline $\mathbf{N}$ & Nama & Warna & Uji & Standa \\
$\mathbf{0}$ & Sampe & & Warn & r SNI \\
& l & & a & 01- \\
& & & & $3471-$ \\
& & & & 2013 \\
\hline
\end{tabular}

\begin{tabular}{|c|c|c|c|c|}
\hline 1 & $\mathrm{~S}_{20}$ & $\begin{array}{l}\text { Kuning } \\
\text { jernih }\end{array}$ & $\begin{array}{l}\text { Norma } \\
1\end{array}$ & \\
\hline 2 & $\mathrm{C}_{1}$ & $\begin{array}{l}\text { Kuning } \\
\text { kecoklata } \\
\mathrm{n}\end{array}$ & $\begin{array}{l}\text { Tidak } \\
\text { norma } \\
1\end{array}$ & Norma \\
\hline 3 & $\mathrm{C}_{2}$ & $\begin{array}{l}\text { Kuning } \\
\text { kecoklata } \\
\text { n }\end{array}$ & $\begin{array}{l}\text { Tidak } \\
\text { norma } \\
1\end{array}$ & \\
\hline 4 & $\mathrm{C}_{3}$ & $\begin{array}{l}\text { Kuning } \\
\text { kecoklata } \\
n\end{array}$ & $\begin{array}{l}\text { Tidak } \\
\text { norma } \\
1\end{array}$ & \\
\hline 5 & $\mathrm{C}_{4}$ & $\begin{array}{l}\text { Kuning } \\
\text { kecoklata } \\
\mathrm{n}\end{array}$ & $\begin{array}{l}\text { Tidak } \\
\text { norma } \\
1\end{array}$ & \\
\hline 6 & $\mathrm{G}_{1}$ & $\begin{array}{l}\text { Kuning } \\
\text { kecoklata } \\
\mathrm{n}\end{array}$ & $\begin{array}{l}\text { Tidak } \\
\text { norma } \\
1\end{array}$ & \\
\hline 7 & $\mathrm{G}_{2}$ & $\begin{array}{l}\text { Kuning } \\
\text { kecoklata } \\
n\end{array}$ & $\begin{array}{l}\text { Tidak } \\
\text { norma } \\
1\end{array}$ & \\
\hline
\end{tabular}




\begin{tabular}{llll}
$\mathbf{8}$ & $\mathrm{G}_{3}$ & Kuning & Tidak \\
& & kecoklata & norma \\
& & $\mathrm{n}$ & 1 \\
$\mathbf{9}$ & $\mathrm{G}_{4}$ & $\begin{array}{l}\text { Kuning } \\
\text { kecoklata }\end{array}$ & Tidak \\
& & norma \\
& & $\mathrm{n}$ & 1 \\
$\mathbf{1 0}$ & $\mathrm{G}_{5}$ & $\begin{array}{l}\text { Kuning } \\
\text { kecoklata }\end{array}$ & Tidak \\
& & norma \\
& & n & 1 \\
\hline
\end{tabular}

Sampel standar $\left(\mathrm{S}_{20}\right)$ minyak goreng yang berwarna kuning jernih digunakan menjadi acuan sebagai sampel standar yang memiliki warna "normal" berdasarkan Standar Mutu Minyak Goreng SNI 01-3471-2013. Sehingga semua sampel uji dikatakan memiliki warna yang "tidak normal" karena memiliki warna lebih gelap dari sampel $\mathbf{S}_{20}$.

Perubahan warna minyak goreng terjadi akibat proses penggorengan, kemudian disimpan dan dipanaskan kembali. Suhu pemanasan yang terlalu tinggi menyebabkan sebagian minyak teroksidasi. Selain itu minyak yang terdapat didalam suatu bahan, ketika dipanaskan akan mengekstraksi zat warna yang terdapat dalam bahan tersebut (Putri, 2015). Selain itu senyawa volatil yang terkandung di dalam minyak goreng akan menguap selama proses penggorengan berlangsung sehingga menyebabkan warna pada minyak goreng semakin gelap (Serjouie et al, 2010).

\section{Hasil Uji Bau}

Tabel 4.7 Hasil Uji Organoleptik Bau Minyak Goreng

\begin{tabular}{|c|c|c|c|c|}
\hline No & $\begin{array}{l}\text { Nama } \\
\text { Sampel }\end{array}$ & Bau & $\begin{array}{c}\text { Uji } \\
\text { Bau }\end{array}$ & $\begin{array}{c}\text { SNI 01- } \\
3471- \\
2013\end{array}$ \\
\hline 1 & $\mathrm{~S}_{20}$ & $\begin{array}{l}\text { Bau } \\
\text { khas }\end{array}$ & Normal & \\
\hline 2 & $\mathrm{C}_{1}$ & $\begin{array}{l}\text { Bau } \\
\text { tengik }\end{array}$ & $\begin{array}{c}\text { Tidak } \\
\text { normal }\end{array}$ & \\
\hline 3 & $\mathrm{C}_{2}$ & $\begin{array}{l}\text { Bau } \\
\text { tengik }\end{array}$ & $\begin{array}{l}\text { Tidak } \\
\text { normal }\end{array}$ & Normal \\
\hline 4 & $\mathrm{C}_{3}$ & $\begin{array}{l}\text { Bau } \\
\text { tengik }\end{array}$ & $\begin{array}{l}\text { Tidak } \\
\text { normal }\end{array}$ & \\
\hline 5 & $\mathrm{C}_{4}$ & $\begin{array}{l}\text { Bau } \\
\text { tengik }\end{array}$ & $\begin{array}{l}\text { Tidak } \\
\text { normal }\end{array}$ & \\
\hline 6 & $\mathrm{G}_{1}$ & $\begin{array}{l}\text { Bau } \\
\text { tengik }\end{array}$ & $\begin{array}{l}\text { Tidak } \\
\text { normal }\end{array}$ & \\
\hline 7 & $\mathrm{G}_{2}$ & $\begin{array}{l}\text { Bau } \\
\text { tengik }\end{array}$ & $\begin{array}{l}\text { Tidak } \\
\text { normal }\end{array}$ & \\
\hline 8 & $\mathrm{G}_{3}$ & $\begin{array}{l}\text { Bau } \\
\text { tengik }\end{array}$ & $\begin{array}{l}\text { Tidak } \\
\text { normal }\end{array}$ & \\
\hline 9 & $\mathrm{G}_{4}$ & $\begin{array}{l}\text { Bau } \\
\text { tengik }\end{array}$ & $\begin{array}{l}\text { Tidak } \\
\text { normal }\end{array}$ & \\
\hline 10 & $\mathrm{G}_{5}$ & $\begin{array}{l}\text { Bau } \\
\text { tengik }\end{array}$ & $\begin{array}{l}\text { Tidak } \\
\text { normal }\end{array}$ & \\
\hline
\end{tabular}

Bau tengik pada sampel uji diketahui setelah dilakukan uji bau oleh panelis. Minyak goreng yang terhidrolisis akan bereaksi menjadi gliserol dan asam lemak bebas. Ketika dipanaskan, gliserol akan menghasilkan senyawa akrolein. Akrolein ini adalah senyawa aldehid yang bersifat volatil dan akan menguap sehingga menyebabkan bau tengik.

\section{Hasil Uji Kadar Air}

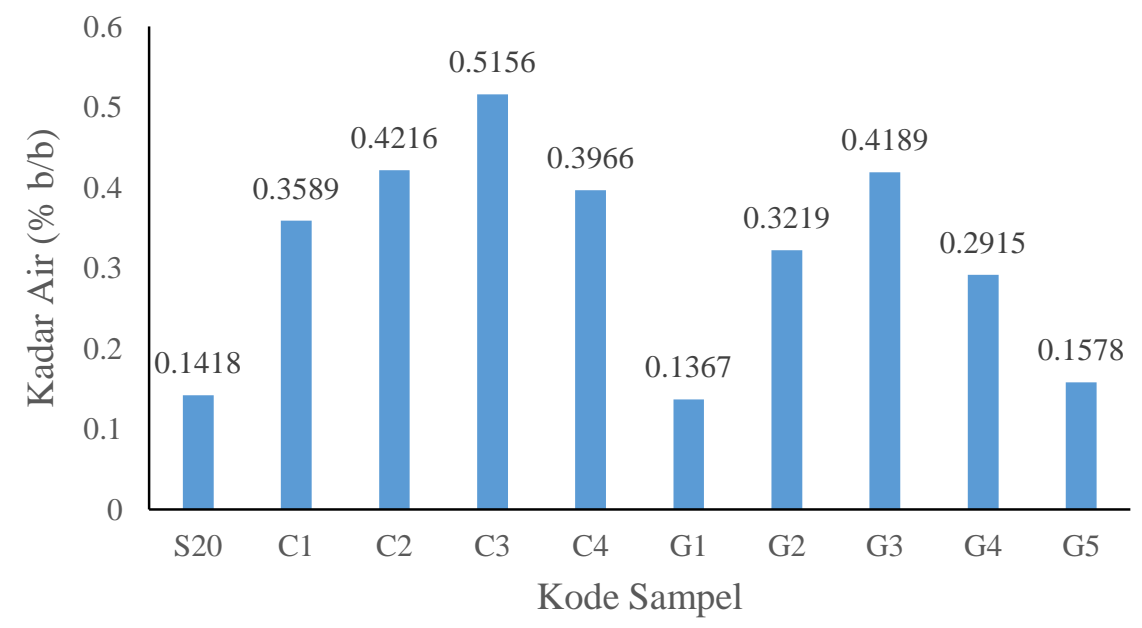

Grafiik Uji Kadar Air Sampel Minyak Goreng 
Berdasarkan grafik, hasil analisis menunjukkan bahwa sebanyak 8 sampel uji minyak goreng melebihi syarat mutu yang ditetapkan oleh SNI 01-3741-2013 yaitu 0,15\% (b/b). Hasil analisis yang memenuhi Standar Mutu Minyak Goreng SNI 01-3741-2013 adalah minyak goreng sampel standar $\left(S_{20}\right)$ dan $G_{1}$ dengan nilai kadar airnya berturut-turut $0,1418 \%$ (b/b) dan 0,1367 $\%$ (b/b). Sampel $\mathrm{G}_{1}$ memiliki kadar air lebih rendah dibandingkan dengan standar dimungkinkan karena minyak goreng yang digunakan adalah minyak goreng sania. Selain itu bahan yang digoreng adalah keripik singkong. Singkong yang diiris tipis mengandung air yang lebih sedikit sehingga sedikit uap air yang dihasilkan.

Kadar air tertinggi adalah pada sampel uji $\mathrm{C}_{3}$ yaitu $0,5156 \%(\mathrm{~b} / \mathrm{b})$. Berdasarkan rata-rata nilai, kadar air tertinggi terdapat pada sampel $\mathrm{C}_{1}$ sampai $\mathrm{C}_{4}$ dari penjual makanan cepat saji. Pada penjual makanan cepat saji bahan yang digoreng adalah daging ayam yang dibalut dengan adonan tepung. Secara alami kandungan air pada daging ayam lebih banyak daripada gorengan tahu, tempe, singkong dan pisang. Dan proses pencelupan pada adonan dilakukan 2 kali agar terbentuk tekstur yang diinginkan. Ketika bahan digoreng, air di permukaan dan dibagian dalam bahan akan menjadi uap air. Semakin banyak kandungan air bahan yang digoreng maka semakin banyak uap air. Penguapan air bahan secara bersamaan bahan menyerap minyak goreng oleh bahan. Semakin sering penggunaan minyak goreng memberikan efek sinergis meningkatnya kadar air pada minyak goreng yang disebabkan adanya proses pencelupan bahan yang akan digoreng dengan adonan tepung yang telah mengandung air (Chairunisa 2013).

Dengan adanya air, minyak goreng dapat terhidrolisis menjadi gliserol dan asam lemak bebas. Setelah dipanaskan, ikatan pada gliserol akan putus sehingga menyebabkan lepasnya dua molekul air dan membentuk senyawa akrolein dan air. Senyawa akrolein dapat mengiritasi mata dan menimbulkan rasa gatal pada tenggorokan (Kusnandar, 2010). Pembentukan akrolein dapat dilihat pada reaksi:<smiles>[R]OC(=O)C(COC([R])=O)O[R]</smiles>

Gliserol

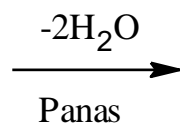

Akrolein<smiles>CCC=O</smiles>

Air
Gambar 4.1 Reaksi Pembentukan Akrolein dan Air

Uji Cemaran Logam

Tabel 4.8 Hasil Analisis Uji Logam Kadmium (Cd)

\begin{tabular}{clcc}
\hline No & $\begin{array}{c}\text { Kode } \\
\text { Sampel }\end{array}$ & $\begin{array}{c}\text { Logam } \\
\text { Kadmium } \\
\text { (Cd) } \mathbf{m g} / \mathbf{k g}\end{array}$ & $\begin{array}{c}\text { Standar } \\
\text { SNI 2013 }\end{array}$ \\
\hline $\mathbf{1}$ & $\mathrm{S}_{20}$ & 0,0002 & \\
$\mathbf{2}$ & $\mathrm{C}_{1}$ & 0,0001 & \\
$\mathbf{3}$ & $\mathrm{C}_{2}$ & 0,0002 & \\
$\mathbf{4}$ & $\mathrm{C}_{3}$ & 0,0003 & \\
$\mathbf{5}$ & $\mathrm{C}_{4}$ & 0,0003 & $\leq \mathrm{Maks}$ \\
$\mathbf{6}$ & $\mathrm{G}_{1}$ & 0,0003 & $0,2 \mathrm{mg} / \mathrm{kg}$ \\
$\mathbf{7}$ & $\mathrm{G}_{2}$ & 0,0002 & \\
$\mathbf{8}$ & $\mathrm{G}_{3}$ & 0,0002 & \\
$\mathbf{9}$ & $\mathrm{G}_{4}$ & 0,0002 & \\
$\mathbf{1 0}$ & $\mathrm{G}_{5}$ & 0,0001 & \\
\hline
\end{tabular}

Tabel 4.9 Hasil Analisis Uji Logam Timbal $(\mathrm{Pb})$

\begin{tabular}{clcc}
\hline No & $\begin{array}{c}\text { Kode } \\
\text { Sampel }\end{array}$ & $\begin{array}{c}\text { Logam } \\
\text { Timbal }(\mathbf{P b}) \\
\mathbf{m g} / \mathbf{k g}\end{array}$ & $\begin{array}{c}\text { Standar } \\
\text { SNI 2013 }\end{array}$ \\
\hline $\mathbf{1}$ & $\mathrm{S}_{20}$ & 0,0001 & \\
$\mathbf{2}$ & $\mathrm{C}_{1}$ & 0,0011 & \\
$\mathbf{3}$ & $\mathrm{C}_{2}$ & 0,0002 & \\
$\mathbf{4}$ & $\mathrm{C}_{3}$ & 0,0001 & \\
$\mathbf{5}$ & $\mathrm{C}_{4}$ & 0,0005 & $\leq \mathrm{Maks} 0,1$ \\
$\mathbf{6}$ & $\mathrm{G}_{1}$ & 0,0004 & $\mathrm{mg} / \mathrm{kg}$ \\
$\mathbf{7}$ & $\mathrm{G}_{2}$ & 0,0005 & \\
$\mathbf{8}$ & $\mathrm{G}_{3}$ & 0,0009 & \\
$\mathbf{9}$ & $\mathrm{G}_{4}$ & 0,0003 & \\
$\mathbf{1 0}$ & $\mathrm{G}_{5}$ & 0,0006 & \\
\hline
\end{tabular}

Hasil analisis cemaran logam kadmium (Cd) dan timbal $(\mathrm{Pb})$ sampel uji minyak goreng tidak melebihi batas maksimal atau sudah memenuhi Standar Mutu Minyak Goreng SNI 01-37412013 yaitu $\leq 0,2 \mathrm{mg} / \mathrm{kg}$ untuk Kadmium $(\mathrm{Cd})$ dan $\leq 0,1 \mathrm{mg} / \mathrm{kg}$ untuk Timbal $(\mathrm{Pb})$. Bahan pangan berlemak umumnya mengandung 
logam dalam jumlah yang sangat sedikit, logam ini biasanya sudah terdapat secara alami dalam bahan namun tetap dalam jumlah aman (Widowati, 2011). Pada proses penggorengan pada daging ayam broiler menyebabkan protein yang mengikat logam $\mathrm{Cd}, \mathrm{Fe}, \mathrm{Zn}, \mathrm{Pb}$, dan $\mathrm{Cu}$ akan terdenaturasi sehingga kandungan logam akan mengendap didalam minyak goreng yang digunakan untuk menggoreng (Djohan et al, 2015). Rendahnya kandungan logam dalam sampel uji minyak goreng juga disebabkan oleh alat-alat untuk menggoreng yang digunakan oleh penjual gorengan dan cepat saji digunakan dalam keadaan bersih dan tidak terkontaminasi dengan alat atau bahan lain yang mengandung unsur logam.

\section{Uji Bilangan Asam}

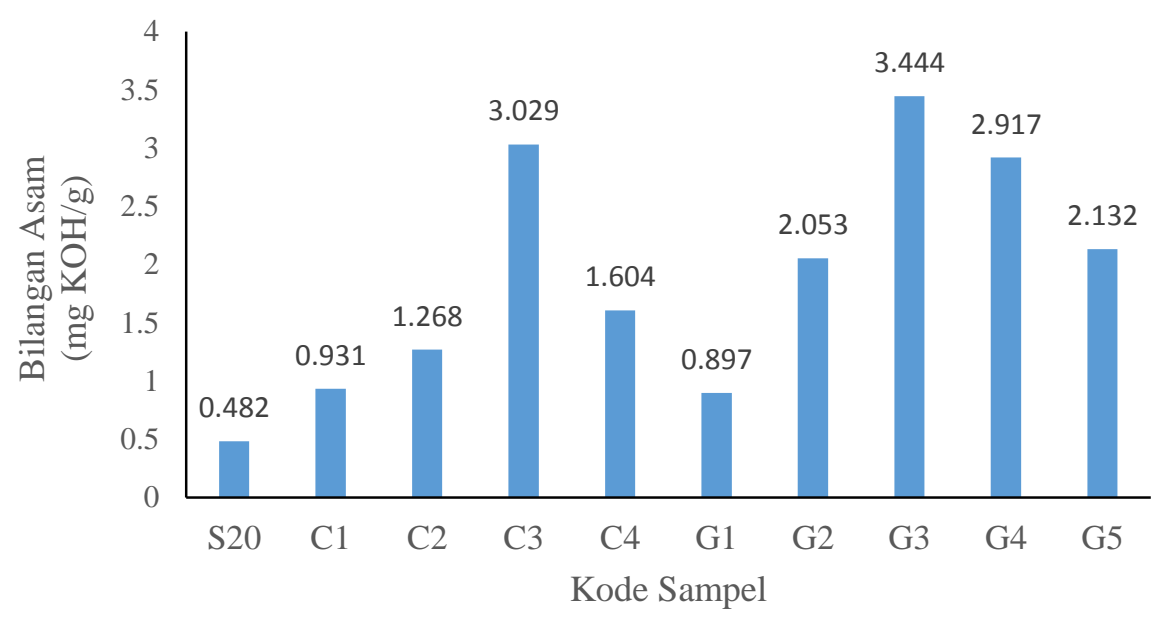

Grafik 4.2 Uji Bilangan Asam Sampel Uji

Hasil analisis dari 9 sampel uji menunjukkan bahwa bilangan asam yang dihasilkan dari semua sampel uji minyak goreng penjual gorengan melebihi standar yang ditetapkan oleh SNI 01-3741-2013 yaitu maksimal 0,6 mg $\mathrm{KOH} / \mathrm{g}$. Untuk hasil analisis pada sampel standar yang belum digunakan yaitu $0,482 \mathrm{mg}$ $\mathrm{KOH} / \mathrm{g}$. Namun setelah minyak goreng mengalami proses pemanasan, kandungan<smiles>[R]C(=O)OCC(COC([R])=O)OC([R])=O</smiles><smiles>[16OH]</smiles><smiles>C1CCCCC1</smiles>

Air

\subsection{Reaksi Hidrolisis}

asam lemak jenuhnya akan menurun dan meningkatkan kandungan asam lemak bebas. Asam lemak bebas terbentuk karena proses oksidasi (Aminah, 2010) serta proses hidrolisis lemak yang disebabkan oleh air dengan katalis enzim atau panas pada ikatan trigliserida. Trigliserida mengandung air kemudian deberi energi panas akan menghasilkan asam lemak bebas dan gliserol seperti reaksi dibawah ini :<smiles>[R]C(=O)O</smiles>

Asam Lemak Bebas

Gliserol

Gambar

Sedangkan proses oksidasi dapat berlangsung akibat terjadinya kontak antara sejumlah oksigen dengan minyak goreng. Terjadinya reaksi oksidasi akan mengakibatkan bau tengik 
pada minyak goreng (Ketaren dalam Chairunisa, 2013). Meskipun tidak ada sampel uji yang memenuhi Standar Mutu Minyak Goreng SNI 01-3741-2013, namun smapel uji $\mathrm{G}_{1}$ adalah sampel uji dengan kandungan bilangan asam lemak bebas paling rendah yaitu $0,897 \mathrm{mg} \mathrm{KOH} / \mathrm{kg}$. Bahan yang digoreng adalah keripik singkong yang pada pengujian kadar air memiliki nilai kadar air paling rendah.
Sedangkan sampel uji dengan kandungan bilangan asam lemak bebas paling tinggi yaitu sampel uji $\mathrm{G}_{3}$ kemudian diikuti oleh sampel uji $\mathrm{C}_{3}, \mathrm{G}_{4}, \mathrm{G}_{5}$ dan $\mathrm{G}_{2}$. Rata-rata kandungan asam lemak bebas rendah pada sampel uji adalah pada sampel $\mathrm{C}_{1}, \mathrm{C}_{2}$, dan $\mathrm{C}_{4}$ yang diambil dari penjual cepat saji . Hal ini dikarenakan jenis bahan yang digoreng lebih sedikit.

\section{Hasil Uji Peroksida}

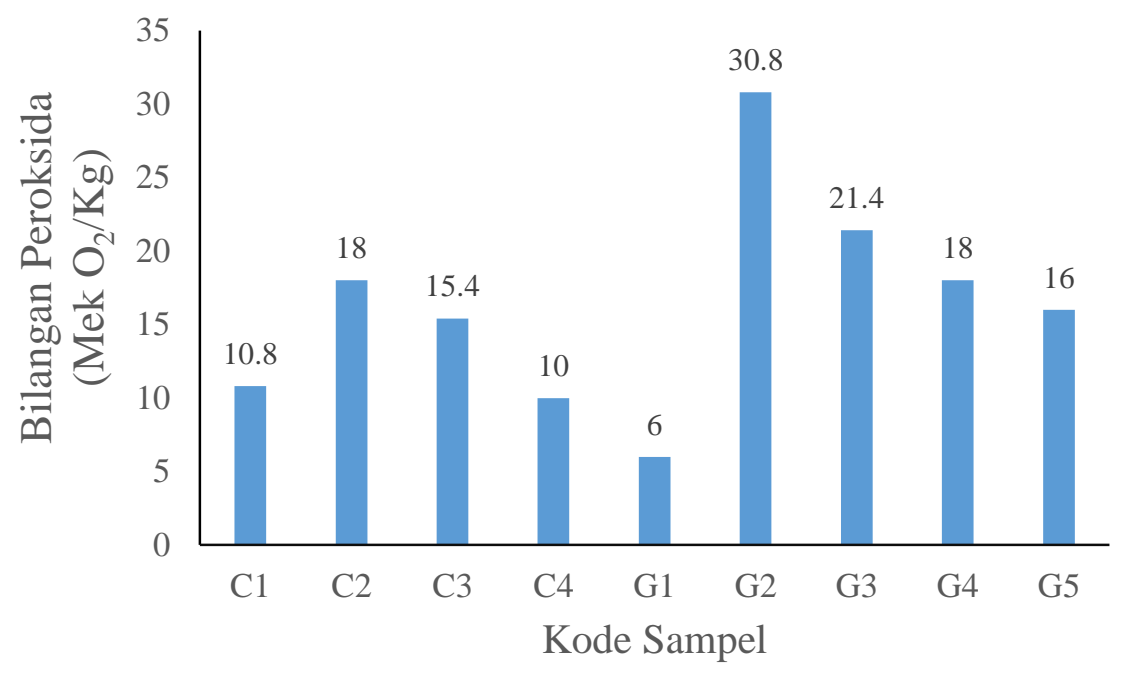

Grafik 4.3 Uji Bilangan Peroksida Minya Goreng

Berdasarkan hasil analisis uji bilangan peroksida secara keseluruhan dari 9 sampel uji menunjukkan bahwa 7 sampel diantaranya mengandung bilangan peroksida melebihi standar yang ditetapkan oleh SNI 01-37412013 yaitu maksimal $10 \mathrm{mek} \mathrm{O}_{2} / \mathrm{kg}$. Sampel yang memenuhi standar SNI 01-3741-2013 yaitu sampel $\mathrm{C}_{4}$ dan $\mathrm{G}_{1}$. Bilangan peroksida tertinggi pada sampel uji minyak goreng $\mathrm{G}_{2}$ yaitu sebesar 32,8 mek $\mathrm{O}_{2} / \mathrm{kg}$. Bahan yang digoreng adalah pisang molen, pisang goreng, tahu isi, lumpia, dan roti goreng. Hal ini disebabkan karena penggorengan yang dilakukan secara terus menerus hingga bahan yang digoreng habis. sedangkan kandungan bilangan peroksida terendah adalah sampel uji minyak goreng $\mathrm{G}_{1}$ yaitu sebesar 6 mek $\mathrm{O}_{2} / \mathrm{kg}$. Sampel uji $\mathrm{G}_{1}$ menggoreng keripik singkong yang bahanya diiris tipis sehingga menggoreng lebih cepat. Sedangkan pada sampel uji $\mathrm{C}_{4}$, bahan yang digoreng adalah ayam krispi akan tetapi penjual hanya menggoreng 1 kali untuk produksi 1 hari. Bilangan peroksida juga dipengaruhi oleh karakteristik bahan yang digoreng berbeda. Semakin tebal bahan yang digoreng maka semakin lama proses penggorengan yang dilakukan. Rata-rata bilangan peroksida tertinggi pada sampel $\mathrm{Uji}$ $\mathrm{G}_{2}, \mathrm{G}_{3}$, dan $\mathrm{G}_{4}$ pada penjual gorengan. Hal ini disebakan banyaknya jenis bahan yang digoreng dengan ketebalan yang berbeda-beda sehingga makin lama waktu yang dibutuhkan untuk menggoreng.

\section{Penutup \\ Kesimpulan}

Faktor-faktor yang mempengaruhi kualitas minyak goreng adalah warna dan bau, kadar air, bilangan asam, bilangan peroksida, dan cemaran logam pada minyak goreng.

Sampel uji yang masih layak untuk digunakan adalah sampel $G_{1}$ karena masih memenuhi Standar Mutu Minyak Goreng SNI 01-37412013 (uji kadar air, uji logam, dan uji bilangan peroksida) akan tetapi pada uji warna memiliki warna yang lebih gelap dari sampel uji lainnya dan pada uji bilangan asam lemak bebas tidak 
memenuhi Standar. Dalam uji bilangan asam lemak bebas, semua sampel uji tidak memenuhi Standar SNI ; Uji bilangan peroksida hanya sampel uji $\mathrm{C}_{4}, \mathrm{G}_{1}$ yang memenuhi Standar ; sedangkan uji cemaran logam semua sampel uji yang memenuhi Standar. Kelayakan minyak goreng yang dipakai oleh penjual gorengan dan penjual cepat saji sudah mengalami penurunan mutu yang dinalisis berdasarkan Standar Mutu Minyak Goreng SNI 01-3741-2013.

\section{Saran}

Perlunya penelitian lebih lanjut untuk meneliti sampel gorengan secara langsung dan mengetahui berapa kali maksimal penggunan minyak goreng. Selain itu perlunya ada penelitian lanjutan tentang cara menjernihkan minyak goreng agar dapat dimanfaatkan kembali tanpa memberi dampak negatif pada tubuh

\section{DAFTAR PUSTAKA}

Aminah, S. (2010), Bilangan Peroksida Minyak Goreng Curah dan Sifat Organoleptik Tempe pada Pengulangan Gorengan, Jurnal Pangan dan Gizi, Vol. 01, No. 01, Universitas Muhammadiyah Semarang, Semarang.

BPS-Badan Pusat Statistik. (2017), Survey Sosial Ekonomi Nasional, jakarta

Chairunisa. (2013), Uji Kualitas Minyak Goreng Pada Pedagang Gorengan di Sekitar Kampus UIN Syarif Hidayatullah Jakarta, Skripsi, UIN Syarif Hidayatullah, Jakarta.

Djohan et al. (2015), Akumulasi Logam Berat Dalam Daging Dan Tulang Ayam Kampung Dan Ayam Negeri, Universitas Gadjah Mada, Yogyakarta.

Dwiloka dan Atmomarsono. (2010), Kandungan Logam Berat $\mathrm{Pb}$ daging dada dan Paha Ayam Broiler yang Dipelihara dengan Sistem Kandang Panggung Setelah Direbusdan Dikukus, Skripsi, Universitas Diponegoro, Semarang.

Fauziah, dkk. (2014), Analisis Kadar Asam Lemak Bebas dalam Gorengan dari
Minyak Bekas Hasil Penggorengan Makanan Jajanan di Workshop Unhas, Jurnal Teknologi Pangan, Makassar.

Hambali, E. (2007), Teknologi Bioenergi, Agromedia Pustaka, Jakarta.

Haryono et al. (2010), Pengolahan Minyak Kelapa Sawit Bekas Menjadi Biodiesel Studi Kasus : Minyak Goreng Dari KFC Dago Bandung, Pengembangan Teknologi Kimia untuk Pengolahan Sumber Daya Alam Indonesia, Prosiding Seminar Nasional teknik Kimia "Kejuangan", Yogyakarta.

Kusnandar, F. (2010), Kimia Pangan Komponen Makro, Dian Rakyat, Jakarta

Noriko, N dkk. (2012), Analisis Penggunaan dan Syarat Mutu Minyak Goreng pada Penjaja Makanan Di Fod Court UAI, Jurnal Al-Azhar Indonesia Seri Sains dan Teknologi, Universitas Al-Azhar Indonesia, Jakarta.

Putri, Sarah. (2015), Efek Lama Pemanasan Terhadap Bilangan Peroksida Minyak Goreng Yang Berpotensi Karsinogenik Pada Pedagang Gorengan Di Kelurahan Pasar Minggu, Skripsi, Universitas Islam Negeri Syarif Hidayatullah , Jakarta.

Serjouie et al. (2010), Effect Of VegetasieBased Oil On Psychochemical Properties of Oil During Deep Fat Frying, American Journal Of Food Technologi, Malaysia.

SNI-Standar Nasional Indonesia. (2009). Batas Maksimum Cemaran Logam Dalam Pangan, Badan Standarisasi Nasional (BSN), Jakarta.

SNI-Standar Nasional Indonesia. (2013), Standar Mutu Minyak Goreng, Badan Standarisasi Nasional (BSN), Jakarta.

Widowati, H. (2011), Pengaruh Logam Cd dan $\mathrm{Pb}$ Terhadap Perubahan Warna Batang Sayuran, El-Hayah 